\title{
THE EFFECT OF CONSUMERS' BEHAVIOR AND PERCEIVED RISK ON PURCHASE DECISIONS AMONG ONLINE SHOP CONSUMERS
}

\author{
Dewi Indriani Jusuf ${ }^{1}$, Dadang Munandar ${ }^{2}$ \\ 1dewijusuf@iwu.ac.id \\ International Women University \\ Jl. Pasir Kaliki No.179 A, Kb. Jeruk, Kec. Cicendo, Kota Bandung, Jawa Barat 40173
}

received: 6/9/21; revised: 28/10/21; approved: 20/12/21

\begin{abstract}
The goal of the research is to know the effect of the consumer behavior and perceived risk on, the consumers' buying decision. This research employs a quantitative approach, descriptive and verified design. As much as 100 consumers are selected as respondents using a purposive method. The instrument of data collection is questionnaire. The data analysis used is Structural Equation Modeling. The research results show that the consumer behavior and perceived risk affects the consumer buying decision significantly. The biggest effect of the consumer behavior dimension on the buying decision variable is a personal factor and the biggest effect of the consumer behavior variable is on payment method dimension. The perceived risk contributes to the consumer buying decision significantly. It also proves that that the emerging of the online shops contributes shifting of the consumer behavior from a conventional business transaction into a digital one among the consumers.
\end{abstract}

Keywords: consumer behavior; perceived risk; purchase decision; online shop consumers; structural equation modeling

\section{INTRODUCTION}

As we know, at present in the digital economy era, the trend of business models has shifted from conventional business models to the digital ones globally. This occurs in the Indonesian business world as well. Currently, various online businesses ranging from news, transportation, online stores, online malls, online bookstores, online ticket businesses, online food and so on have emerged through their web sites. That is why, according to the research by Katawetawaraks \& Wang (2013) those phenomena trigger managerial implication, namely the web sites should be improved well and continuously. This finding is strengthened by Wen (2009) and Mazaheri, et al. (2011) saying that the web sites are the antecedent of consumer online buying intention.

As a matter of fact, digital technology provides both opportunities and challenges. One of the potential chances is that we can make online business transactions more easily through the medium of the Internet, that has been changed conventional buying process into the online one (Snowwaney \& Chincholkar, 2019), where we can sell and buy products using only a computer or cell phone as a means of business transactions. This is called as telepresence as the antecedent of the online consumer behavior (Lee \& Chen, 2010). Furthermore, previous research results show that consumers tend to do business transactions online. More and more consumers are interested in watching advertisements through Youtube than television. According to the research conducted by Comegys, et al. (2006) buying decision process consists of several process. This fact shows that there is a shift in consumer behavior from conventional behavior to digital one. Currently in Indonesia, various online businesses have sprung up, ranging from news, transportation, online stores, online malls, online bookstores, online ticket businesses, online food and so on, faster than ever. This phenomena are called as the digital platform (Dahiya \& Gayatri, 2017).

In this study, the author wants to explore the role of consumer behavior and perceived risk on consumer purchasing decisions as implemented by the Shopee online shop. This online shop sells online products ranging from food additives, accessories, men's and women's clothing, household appliances, electronic equipment, as well as car equipment and accessories.

Problems of this research are: what factors emerge from consumer behavior and consumer perceived risk variables that affect purchasing decisions among the consumers studied? The purpose of this research is to find out significant factors of consumer behavior and consumer perceived risk affecting purchasing decisions on Shopee online store consumers. 
Experts on consumer behavior named Kotler and Keller (2012) say that the factors affecting consumer behavior are cultural, social, personal, and psychological factors. Culture is the most dominant factor influencing consumer behavior. Social factors that influence consumer behavior are constructed by reference groups, family, social roles and status. While personal factors consist of age, life cycle, occupation, economic environment, personality, self-concept, lifestyle, and values. While the psychological factors consist of motivation, perception, learning and attitude. Further more purchasing decisions consist of product selection, trademark selection, distribution selection, purchase time, and payment methods. In addition, according to them, purchasing decisions are not only affected mainly by consumer behavior but there are other factors called moderating factors, namely perceived risk factors consisting of functional risk, physical risk, financial risk, social risk, psychological risk, and time risk.

Furthermore, consumer behavior theory enables businesses to understand more about their target consumers and thus be able to design products, services and corporate culture to influence buying habits. Understanding consumer behavior enables businesses to know: a) What consumers think of our brand versus competitors; $b$ ) How do they choose a product or service among various alternative products; c) Their behavior when shopping; d) How the environment around them affects their buying behavior; e) What marketing campaigns or pricing strategies can they respond to; f) Their preferred payment method; and g) What products or services are they looking for to fulfill their needs.

As we know that consumer purchasing habits are constantly evolving, and the way businesses think about them has changed too. Initially, it was believed that consumers were rational and behaved in a consistent manner. However, as time goes on and more sophisticated research has been carried out, it has become clear that consumers often behave irrationally with various factors that determine buying decisions and habits. Moreover, consumers are then segmented, and user experience is analyzed to understand how they form buying habits. Post-purchase activities and habits are also studied so that the customer journey can be mapped from the first decision, through consideration, purchase, and post-purchase satisfaction. Payment methods and purchasing preferences have also evolved. Currently, most people like to conduct online purchase. Based on the research that has been conducted by the Association of the Internet provider in Indonesia, the active Internet users grows fast and it reaches 64,7\% in 2019 (Hermawan, 2019). Moreover, the similar study done by Tayipnapis, et al. (2020) reveals that the digital economy growth in Indonesia is 6.5 million per year for online shopping. In line with those studies, based on Google research, Indonesia's digital economy will be worth as much as US\$ 146 billion by 2025 as quoted by Tempo English Magazine (2021).

\section{METHODS}

Based on the relationship of the variables studied, in this research the current author used a quantitative approach, descriptive and verification design, and survey methods. A total of 100 Shopee consumers in Bandung have been selected using the purposive method. The data collection instrument used was a questionnaire. The validity and reliability of the instrument will be carried out using the Pearson Product Moment and Cronbach's Alpha correlation. The analytical technique used is partial least square-based structural equation modeling (PLS SEM) with the help of Smart PLS version 3. According to Narimawati, et al. (2020) using PLS-SEM analysis minimally needs only sample size 10 times number of indicators used to measure 1 latent variable or 10 times number of the major structural paths into a certain latent variable within the structural model concerned. PLS SEM allows small sample size as this has been practiced by Chin and Newsteed (1999) in his article as quoted by Sarwono (2018). They used only 20 (twenty) data in their research using the PLS SEM correctly.

The research hypotheses are as follows: The first hypothesis: The relationship between consumer behavior and consumer purchasing decisions. $\left(\mathrm{H}_{0}\right)$ Consumer behavior has no effect on consumer purchasing decisions significantly among the Shopee online store consumers in Bandung; $\left(\mathrm{H}_{1}\right)$ Consumer behavior affects consumer purchasing decisions significantly among the Shopee online store consumers in Bandung.

The second hypothesis: The relationship between consumer perceived risk and consumer purchasing decisions. $\left(\mathrm{H}_{0}\right)$ The consumer perceived risk has no effect on consumer purchasing decisions significantly among the Shopee online store consumers in Bandung; $\left(\mathrm{H}_{1}\right)$ The consumer perceived risk affects on consumer purchasing decisions significantly among the Shopee online store consumers in Bandung.

\section{RESULTS}

Data Collection Instrument Validity and Reliability: The Pearson correlation coefficient of all items used in the questionnaire is more than 0.3 , meaning that all questions are valid. Cronbach's Alpha value is 0.865 which is more than 0.6 indicating that all questions are reliable. Thus, the data collection instrument is valid and reliable. The calculation results will be shown in Figure 1 and 2. 


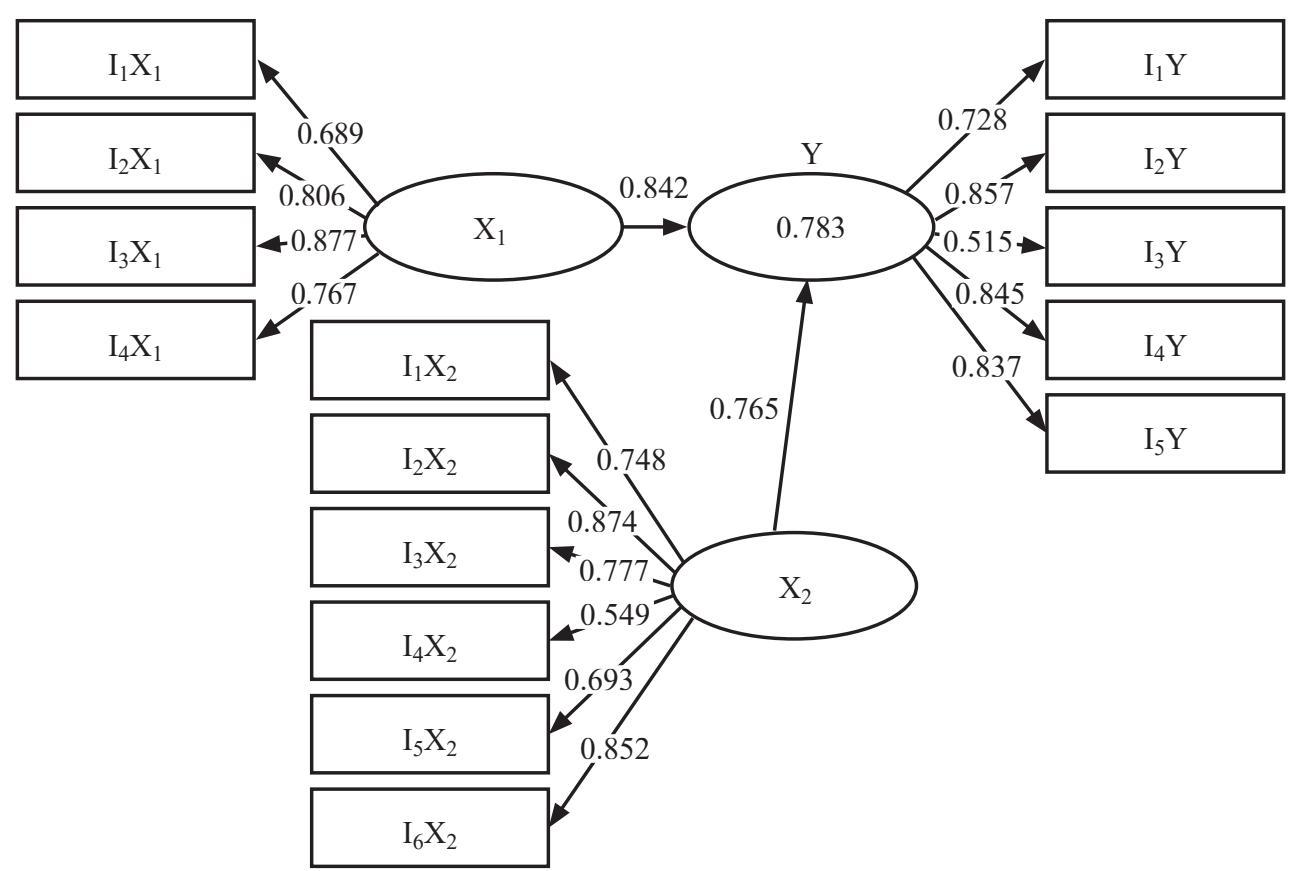

Where:

Figure 1. Values of Path Coefficient

$\begin{array}{llllll}\mathrm{X}_{1} & \text { : Consumer Behavior } & \mathrm{I}_{1} \mathrm{X}_{2} & \text { : Functional Risk } & \mathrm{Y} & \text { : Buying/Purchase Decision } \\ \mathrm{I}_{1} \mathrm{X}_{1} & \text { : Cultural Factors } & \mathrm{I}_{2} \mathrm{X}_{2} & \text { : Physical Risk } & \mathrm{I}_{1} \mathrm{Y} & \text { : Product Selection } \\ \mathrm{I}_{2} \mathrm{X}_{1} & \text { : Social Factors } & \mathrm{I}_{3} \mathrm{X}_{2} & \text { : Financial Risk } & \mathrm{I}_{2} \mathrm{Y} & \text { : Brand Selection } \\ \mathrm{I}_{3} \mathrm{X}_{1} & \text { : Personal Factor } & \mathrm{I}_{4} \mathrm{X}_{2} & \text { : Social Risk } & \mathrm{I}_{3} \mathrm{Y} & \text { : Distribution Selection } \\ \mathrm{I}_{4} \mathrm{X}_{1} & \text { : Psychological Factors } & \mathrm{I}_{5} \mathrm{X}_{2} & \text { : Psychological Risk } & \mathrm{I}_{4} \mathrm{Y} & \text { : Payment Method } \\ \mathrm{X}_{2} & : \text { Perceived Risk } & \mathrm{I}_{6} \mathrm{X}_{2} & \text { : Time Risk } & \mathrm{I}_{5} \mathrm{Y} & \text { : Timing }\end{array}$

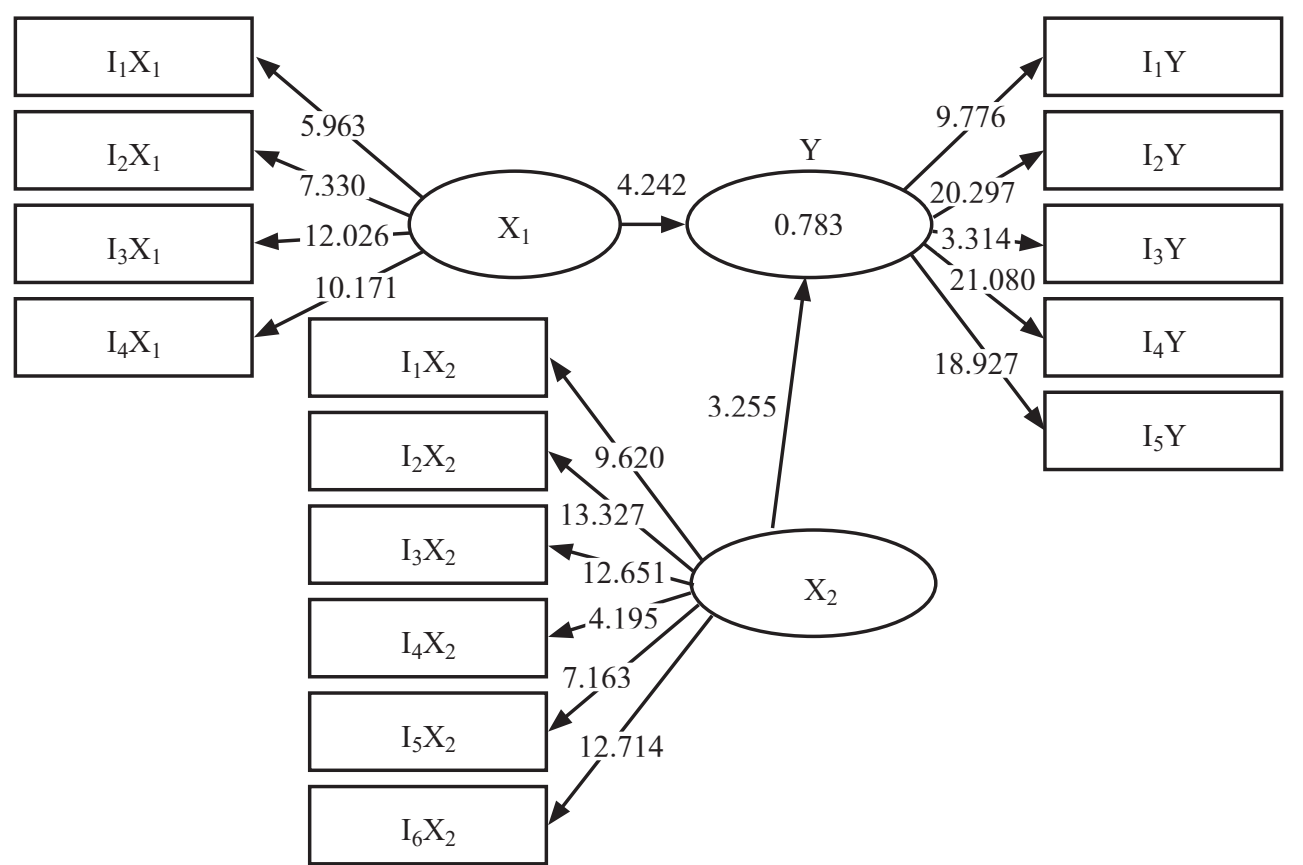

Figure 2. t Values

R square value of 0.783 means that the proportion of variations in the endogenous variable of purchasing decisions with its dimensions can be explained by using the exogenous variable of consumer behavior with its dimensions and by consumer perceived risk its dimensions. 
First: the path coefficient value of the exogenous variable of consumer behavior with its dimensions to the endogenous variable of purchasing decisions with its dimensions. The path coefficient value of consumer behavior with its dimensions on purchasing decisions with its dimensions is as much as 0.842 . This value means the effect of consumer behavior with its dimensions on purchasing decision with its dimensions. Meaning that when the value of consumer behavior with its dimensions increases by one unit, then the value of purchasing decisions with its dimensions increases by 0.842 . This effect is significant because the tobservation (to) of 4.242 as shown in Figure 2 is greater than the $t$ table meaning that $\mathrm{H}_{1}$ is accepted. This means that the consumer behavior has a significant effect on consumer purchasing decisions among Shopee consumers in Bandung and the magnitude of the effect is 0.803 .

Second: the path coefficient value of the consumer perceived risk variable with its dimensions to the endogenous variable of purchasing decisions with its dimensions. The path coefficient value of perceived risk with its dimensions to purchasing decisions with its dimensions is 0.765 . This value means the magnitude of the effect of the risk perception with its dimensions on purchasing decision with their dimensions. When the value of the of risk perception with its dimensions increases by one unit, then the value of purchasing decisions with its dimensions increases by 0.765 . This effect is significant because the tobservation (to) of 3.255 as shown in Figure 2 is greater than the $\mathrm{t}$ table, meaning $\mathrm{H}_{1}$ is accepted. This means that consumer risk perceptions have a significant effect on consumer purchasing decisions among Shopee respondents in Bandung and the magnitude of the effect is 0.803.

The effect of the dimensions of consumer behavior on purchasing decisions is as follows: 1 ) the effect of cultural factors on purchasing decisions is as much as $0.580(0.689 \times 0.842) ; 2)$ the effect of social factors on purchasing decisions is as much as $0.679 ; 3$ ) the effect of personal factors on purchasing decisions is as much as 0.738 ; and 4) the effect of psychological factors on purchasing decisions is as much as 0.646 . The biggest effect on purchase decision is personal factor because this factor predominates other factors that is seen as minor factors compared to the personal factor that determined the purchase decision. This can be understood since the economic consideration composes the personal factor in which when someone want to buy a certain product, he or she will consider first their money availability Kotler and Keller (2012). This is also supported by the research done by Rosemary Wanjiru (2018) stating that personal factors have become a key factors in determining the buying decision.

The effect of consumer behavior on the dimensions of purchase decisions is as follows: 1) the effect of consumer behavior on product selection is as much as $0.613(0.842 \times 0.728) ; 2)$ the effect of consumer behavior on brand selection is as much as $0.722 ; 3$ ) the effect of consumer behavior on distribution selection is as much as 0.434 ; 4) the effect of consumer behavior on the time of purchase is as much as 0.711 ; and 5) the effect of consumer behavior on payment methods is as much as 0.705 . The biggest effect consumer behavior is on brand selection which means that in general consumers considers the brand of the product is important before they decide to buy the product concerned. Because brand functions as identifying differentiation in which the consumer can buy the distinguished product that can satisfy him (Kavaratzis, 2008).

The effect of the dimensions of risk perceived by consumers on purchase decisions is as follows: 1) the effect of functional risk on purchase decisions is as much as $0.572(0.748 \times 0.765) ; 2)$ the effect of physical risk on purchase decisions is as much as $0.669 ; 3$ ) the effect of financial risk on purchase decisions is as much as $0.594 ; 4)$ the effect of social risk on purchase decisions is as much as $0.420 ; 5$ ) the effect of psychological risk on purchase decisions is as much as 0.530 ; and 5) the effect of time risk on purchase decisions is as much as 0.652 . The biggest effect on purchase decision is physical risk. This is logical because when a certain product has potential effect on harming the user (consumer), accordingly, the user will not even buy that product. This has been also proved by Byuka R and Sing S (2015) in their research stating that physical risk has negative effect on the consumer purchase intention.

The effect of consumer risk perception on the dimensions of purchase decisions is as follows: 1) the effect of consumer risk perception on product selection is as much as $0.557(0.765 \times 0.728) ; 2)$ the effect of consumer risk perception on brand selection is as much as $0.656 ; 3$ ) the effect of consumer risk perception on distribution selection is as much as $0.394 ; 4$ ) the effect of consumer risk perception on time of purchase is as much as 0.646 ; and 5) the effect of consumer risk perception on payment methods is as much as 0,640 . The biggest dimension affected is brand selection. This is in line with the above finding meaning that the consumers really consider that brand is important in selecting the products that they are going to buy. Because brand is identical to product itself (Rifta Clifton, 2020).

The model fit of the variables under study will be assessed using the construct and value of reliability and discriminant validity. The value of validity and reliability refers to how much the construct (latent variable) of exogenous variables of $X_{1}$ and $X_{2}$ and endogenous variable of $Y$ underlies their respective dimensions. The validity uses the Rho_A value with a minimum value of 0.5 while for reliability uses Cronbach's alpha value with a minimum value of 0.7 (Hair: 2010). The reliability and validity of consumer behavior, purchase decisions and risk perception values are as follows: 1) variable of consumer behavior $\left(\mathrm{X}_{1}\right)$ is valid because the Rho_A 
value is 0.828 which is more than 0.5 and is also reliable because the value of Cronbach's alpha is $0.797(0.8)$ more than $0.7 ; 2)$ variable consumer perceived risk $\left(\mathrm{X}_{2}\right)$ is valid because the Rho_A value is 0.856 which is more than 0.5 and also reliable because the value of Cronbach's alpha is 0.841 more than $0.7 ; 3$ ) variable of purchase decision $(\mathrm{Y})$ is valid because the Rho_A value is 0.855 which is more than 0.5 and is also reliable because the value of Cronbach's alpha is 0.818 more than 0.7 .

Discriminant validity refers to how much the dimensions reflect the respective latent variables. The discriminant validity uses values of Fornell - Larker. The results are as follows: $\mathrm{X}_{1}$ is as much as $0.788 ; \mathrm{X}_{2}$ as much as 0.890 and $\mathrm{Y}$ as much as 0.730 . In conclusion, all the dimensions of the three latent variables of consumer behavior, risk perception and purchasing decisions are valid because the Fornell - Larcker values are more than 0.5 meaning that it reflects the respective latent variables correctly.

\section{DISCUSSIONS}

The results of the study prove that the consumer behavior has a significant effect on consumer purchase decisions. This is in line with the theory put forward by Kotler and Keller (2012) that the four factors affecting consumer behavior contribute to consumer purchase decisions. Furthermore, it also proves that consumer cultural, social, personal and psychological factors contribute to the shift in consumer behavior studied from conventional purchase decisions to online purchase ones. This can be understood from the respondents' answers about the frequency of purchase products online at the online store. In addition, the existence of the consumer perception variable also affects purchase decisions. This is proved from the results of the previous study showing that the consumer perception variable has a significant effect on consumer purchase decisions as it has been conducted by the present author. Previous research shows that consumer behavior has a significant effect on consumer purchase decisions with an R square value of 0.756 . Meanwhile, the presence of perceived risk variable in the relationship between consumer behavior and purchase decisions contributed to an increase in the value of $\mathrm{R}$ square from 0.756 to 0.783 . This is in line with the research result conducted by Darley, et al. (2010) stating that purchasing decision process is also affected by external factors, beside consumer behavior factors. This increase in value proves that the consumer's risk perception influences purchase decisions. Accordingly, it can be concluded that consumer behavior and perceived risk affect consumer purchase decisions significantly.

From the results of the study also revealed that the consumer's personal factors provide the largest contribution to purchase decisions. This proves that internal drives play an important role in purchase decisions. The importance of age, life cycle, occupation, economic environment, personality, self-concept, lifestyle, and values in deciding whether a consumer will buy a particular product is well understood. Most consumers who buy products online usually come from well-established economic environments. They have good jobs and follow lifestyle trends. As it is known from the web information of the several online stores, most of the products have a higher price compared to conventional stores that offer the same products. In addition, the physical risk dimension provides the largest contribution to consumer purchase decisions. This shows that consumers consider the physical risks that may arise from the products they buy seriously. With that in mind, consumers do not want to take it for granted that the products they buy will not pose a physical risk to them.

It is also known that consumer behavior contributes the most to brand selection. This is also in accordance with the theory put forward by Kotler and Keller (2012) which says that the main stimulus in shaping consumer behavior is product, price, place and promotion (4P). In general, people view product brand as the main thing to consider whether they want to buy a particular product that they need or not. Most online shops ask shoppers to see the brand as one of the factors that will increase their prestige. Other researchers, Cheung, et al. (2003) proved that the role of consumer behavior is important on the buying decision online. From the results of the study it can be seen that Shopee consumer behavior in Bandung has a trend when shopping online will always firstly consider personal factors; then secondly, social factors; thirdly psychological factors and the last is cultural factors.

The biggest effect of consumer perceived risk is on brand selection. This strengthens the assumption that the presence of this second variable contributes significantly to purchase decisions as exogenous variables of consumer behavior. This also proves that the purchase decisions among consumers of the Shopee online store do not only depend on their behavior but also the risks they will experience during the consumption or use of the products. As it has been approved in the study conducted by Arshad, et al. (2015) as well showing that the perceived risk has significant effect on online purchase decision and the similar study done by Ariffin, et al. (2018) stating that five factors of perceived risk contribute a significant negative effect on consumer online buying intention as well as in line with the study conducted by Hong (2012) saying that the order of main risks perception affected purchasing process are financial risk, the performance risk and service risk. Another research done by Vidya, R.M (2019) proved that customer perception affects significantly on buying behavior at the digital marketing. 


\section{CONCLUSIONS}

From the discussion above, the present writer draws conclusions from this research as follows. The variable relationship model under study between consumer behavior, purchase decisions and the perceived risk under study is valid. Consumer behavior has a significant effect on consumer purchase decisions. The biggest effect of consumer behavior dimension on purchase decision variable is personal factor. The second is social factor. The third is the psychological factor and the last is the cultural factor. The major effect of consumer behavior variable is on the dimensions of brand selection factors. The second is the time of purchase factor and is followed by the payment method factor as the third one. The fourth one is the product selection factor and the last is the distribution factor. The greatest effect of consumer perceived risk is on the dimensions of brand selection factors. The second is the time of purchase factor followed by the payment method factor as the third one. The fourth is the product selection factor and the last is the distribution factor. The major effect of the dimensions of consumer risk perception on purchase decision variables is the first physical risk; second time risk; third financial risk; fourth functional risk; the fifth psychological risk and the sixth social risk.

\section{REFERENCES}

Ariffin, S.K., Mohan, T. and Goh, Y.N., 2018. Influence of Consumers' Perceived Risk on Consumers' Online Purchase Intention. Journal of Research in Interactive Marketing.

Arshad, A., Zafar, M., Fatima, I. and Khan, S.K., 2015. The Impact of Perceived Risk on Online Buying Behavior. International Journal of New Technology and Research, 1(8), pp.13-18.

Byuka, R. and Sing, S. 2015. The Effect of Perceived Risk Dimensions on Purchase Intention: An Empirical Evidence from Indian Private Labels Market. American Journal of Business. ISSN 1935 - 5181

Chan, G., Cheung, C., Kwong, T., Limayem, M. and Zhu, L., 2003. Online Consumer Behavior: a Review and Agenda for Future Research. BLED 2003 Proceedings, p.43.

Clifton, R. 2020. Brands and Branding. New York: Bloomberg Press

Comegys, C., Hannula, M. and Väisänen, J., 2006. Longitudinal Comparison of Finnish and US Online Shopping Behaviour Among University Students: The Five-stage Buying Decision Process. Journal of Targeting, Measurement and Analysis for Marketing, 14(4), pp.336-356.

Dahiya \& Gayatri. 2017. A Research Paper on Digital Marketing Communication and Consumer Buying Decision Process: An Empirical Study in the Indian Passenger Car Market. Journal of Global Marketing. 31(2) 1.23. https://doi.org/10.1080/08911762.2017.1365991

Darley, W.K., Blankson, C. and Luethge, D.J., 2010. Toward an Integrated Framework for Online Consumer Behavior and Decision Making Process: A Review. Psychology \& Marketing, 27(2), pp.94-116. https:// doi.org/10.1002/mar.20322

Hair, J.F., Black, W.C, Babin, B.J., \& Anderson, R.E. 2010. Multivariate Data Analysis: A Global Perspective (7th ed.). New Jersey: Pearson Prentice Hall

Hong, Z. 2012. Research on the Influence of Perceived Risk in Consumer Online Purchasing Decision. Physic Procedia. Volume 24, Part B, 2012 pages $1304-1310$

Hermawan, I. 2019. Indonesian Readiness for Digital Economy: Case on Trade Flows in ASEAN Region. In Proceedings of the International Conference on Trade (pp. 211-215).

Indriani, D, J. 2018. Perilaku Konsumen di Masa Bisnis Online. Yogyakarta: Penerbit Andi

Kavaratzis, M. 2008. City Branding: An Effective Assertion of Identity or a Transitory Marketing Trick. Oxford: Blackwell Publishing Ltd.

Katawetawaraks, C \& Wang. C. 2013. Online Shopper Behavior: Influences of Online Shopping Decision. Asian Journal of Business Research Vol. 1, Number 2, 2011

Kotler \& Amstrong, 2012. Principles of Marketing. New Jersey: Pearson

Kotler \& Keller, 2012. Marketing Management. New Jersey: Prentice Hall

Laudon, K.C. \& Trave, C G. 2010. E-Commerce 2010: Business. Technology. Society. New Jersey: Pearson Education

Lee, S.M \& Chen L, 2010. The Impact of Flow on Online Consumer Behavior. Journal of Computer Information Science. Volume 50, 2010. Issue 4

Mazaheri, E., Richard, M.O. and Laroche, M., 2011. Online Consumer Behavior: Comparing Canadian and Chinese Website Visitors. Journal of Business Research, 64(9), pp.958-965.

Narimawati, U., Sarwono, J., Sos, S., Affandi, H.A. and Priadana, H.S., 2020. Ragam Analisis dalam Metode Penelitian: untuk Penulisan Skripsi, Tesis, \& Disertasi. Penerbit Andi.

Sarwono, J. 2018. PLS SEM in Research Data Analysis Application. Washington: Amazon.com 
Snowwaney \& Chincholkar, 2019. Identifying the Factors Impacting Online Consumer Buying Behavior. International Journal of Scientific \& Technology Research Volume 8, Issue 08, August 2019 ISSN 2277-8616 Sangaji \& Sopiah, 2013. Perilaku Konsumen. Yogyakarta: Penerbit Andi

Tayibnapis, A.Z., Wuryaningsih, L.E. and Gora, R., 2018. The Development of Digital Economy in Indonesia. IJMBS International Journal of Management and Business Studies, 8(3), pp.14-18.

Vidya, R.M. 2019. Digital Marketing and Its Effect on Online Consumer Buying Behavior. Journal of Services Research; Gurgaon Vol. 19, Iss. 2, (Oct 2019-Mar 2020): 61-77.

Wanjiru, R. 2018. Influence of Personal Factors on Consumer Purchase Decisions on Mobile Phones in Nairobi County, Kenya. Dspace Collection of thesis and dissertation. https://su-plus.strathmore.edu

Wen, I. 2009. Factors Affecting the Online Travel Buying Decision: a Review. International Journal of Contemporary Hospitality Management. ISSN: 0959-6119 